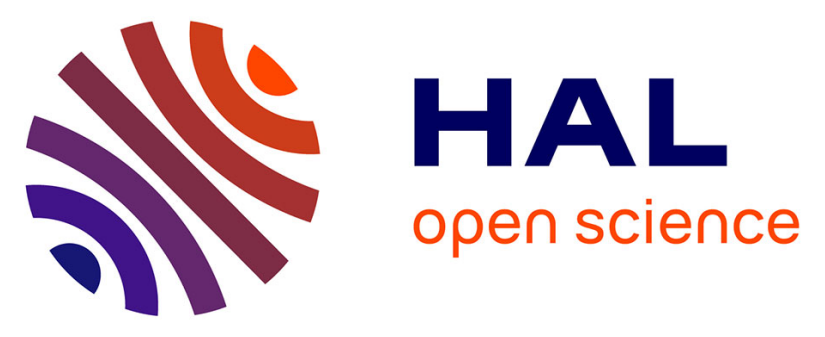

\title{
Fleas (Insecta: Siphonaptera) collected from some small mammals (Mammalia: Rodentia, Eulipotyphla) in Turkey, with new records and new host associations
} Adem Keskin, Ahmet Yesari Selcuk, Haluk Kefelioglu, Jean-Claude Beaucournu

\section{To cite this version:}

Adem Keskin, Ahmet Yesari Selcuk, Haluk Kefelioglu, Jean-Claude Beaucournu. Fleas (Insecta: Siphonaptera) collected from some small mammals (Mammalia: Rodentia, Eulipotyphla) in Turkey, with new records and new host associations. Acta Tropica, 2020, 208, pp.105522. 10.1016/j.actatropica.2020.105522 . hal-02887229

\section{HAL Id: hal-02887229 https://hal.science/hal-02887229}

Submitted on 27 Aug 2020

HAL is a multi-disciplinary open access archive for the deposit and dissemination of scientific research documents, whether they are published or not. The documents may come from teaching and research institutions in France or abroad, or from public or private research centers.
L'archive ouverte pluridisciplinaire HAL, est destinée au dépôt et à la diffusion de documents scientifiques de niveau recherche, publiés ou non, émanant des établissements d'enseignement et de recherche français ou étrangers, des laboratoires publics ou privés. 
1 Fleas (Insecta: Siphonaptera) collected from some small mammals (Mammalia: Rodentia,

2 Eulipotyphla) in Turkey, with new records and new host associations

3

4 Adem Keskin ${ }^{1, *}$, Ahmet Yesari Selçuk ${ }^{2}$, Haluk Kefelioğlu ${ }^{3}$, Jean-Claude Beaucournu ${ }^{4}$

5

${ }^{1}$ Department of Biology, Faculty of Science and Art, Tokat Gaziosmanpaşa University, 60250, Tokat, Turkey.

$6 \quad{ }^{2}$ Yüzüncü Y1l Mahallesi, Tekart Sitesi, 01170, Çukurova, Adana, Turkey

$7{ }^{3}$ Department of Biology, Faculty of Sciences and Arts, Ondokuz May1s University, 55200,

8 Samsun, Turkey

$9 \quad{ }^{4}$ Laboratoire de Parasitologie et Zoologie appliquée, Faculté de Médecine, 2 avenue du Prof.

10 Léon-Bernard, 35043 Rennes cedex, France.

11

12

*Corresponding author:

Adem KESKIN Ph.D.

(D) : 0000-0002-1681-8363

Department of Biology, Faculty of Science and Arts,

Tokat Gaziosmanpasa University, 60250, Tokat, Turkey.

E-mail: ademkeskin@yahoo.com

PH: $+903562521616 / 3036$

13

14

15

16

17

18

19 


\section{ABSTRACT}

3 Fleas (Insecta: Siphonaptera) are among the most common ectoparasites of small mammals.

4 We investigated fleas infesting on the small mammals (Mammalia: Rodentia, Eulipotyphla)

5 from 15 different localities in Turkey. A total of 276 flea (133 males and 143 females)

6 specimens belonging to 32 different flea taxa were collected from 90 (42 males, 16 females and

732 undetermined) small mammals belonging to 20 different species.

8 With many new flea-host associations, the first occurrences of Ctenophthalmus agyrtes

9 peusianus Rosicky, Ctenophthalmus golovi golovi Ioff \& Tiflov, Ctenophthalmus secundus

10 vicarius Jordan \& Rothschild, Doratopsylla dasycnema cuspis Rothschild, Leptopsylla algira

11 popovi (Wagner \& Argyropulo) and Rhadinopsylla pentacantha (Rothschild) fleas were 12 reported in Turkey. In addition, three flea species, Ctenophthalmus coniunctus Peus,

13 Ctenophthalmus contiger Peus, and Palaeopsylla incisa Peus, are reported for only the second

14 time since their original descriptions.

15 Keywords: Ectoparasite, first record, geographical distribution, host associations, rodents.

\section{INTRODUCTION}

Fleas (Insecta: Siphonaptera) comprise approximately 2700 described species and subspecies

19 placed in 18 families and 220 genera (Durden and Hinkle, 2018). The majority (94\%) of all known species of fleas are parasites of mammals; the remaining $(6 \%)$ are parasites of birds.

21 Some fleas (such as Pulex irritans Linnaeus, Xenopsylla cheopis Rothschild, Ctenocephalides

22 felis Bouché, Ctenocephalides canis Curtis, and Tunga penetrans Linnaeus) have medical 23 importance, and they are vectors for the several infectious diseases and can also cause serious

24 skin infestation (such as tungiasis) (Bitam et al., 2010). 
1 Except for the records of widespread flea species and descriptions of new taxa, the flea fauna 2 of Turkey is poorly studied. Peus (1977, 1978a, 1978b) performed most detailed studies on 3 fleas of Turkey and he reported a total of 83 flea species (with subspecies); of these, 22 species 4 and 3 subspecies were newly described. Orhan \& Beaucournu $(1982,1986)$ found a total of 22 5 species of fleas infesting rodents in central and western Anatolia. Aktaş (1987a, 1987b, 1988, $61989,1990,1999)$ contributed considerably to the flea fauna of Turkey. In his studies on the 7 fleas infesting wild mammals, he described four new flea taxa (three new species and one new 8 subspecies) and reported many new records for Turkey. From 2000 to 2018, systematic studies 9 on fleas in Turkey almost stopped and were limited to reports of widespread fleas in some veterinary studies. Recently, Keskin and Beaucournu described five new taxa (Keskin and Beaucournu, 2019a, 2019b; Keskin, 2020) and reported several new flea records for Turkey 12 (Keskin et al., 2019). However, we do not have enough information on the faunal composition of fleas in Turkey. Moreover, distributions and host associations of many flea species are poorly 14 known.

From an epidemiological point of view, the global and regional distribution of fleas and fleaborne pathogens makes them emerging or re-emerging threats to the health of humans and animals. Therefore, studies on flea-host associations are essential to evaluate the ecology of fleas and their potential role in the transmission of zoonotic pathogens. In the present study, we investigated on fleas infesting small mammals in 15 different localities in Turkey. Here, we report many new flea-host associations for Turkey. Also, presence of some fleas in Turkey are documented for the first time. Three flea species are also reported for only the second time since their original descriptions. We believe the present study provides comprehensive information for further studies on fleas and flea-borne infectious agents. 
2 From October 2017 to February 2019, fleas were collected from wild mammals (Mammalia:

3 Rodentia, Eulipotyphla) from 15 different localities in Turkey (Fig. 1). Small mammals were

4 captured from different habitats at each sampling locality with metal and plastic traps (Sherman 5 and Economy Mammal Trip-Trap) baited with peanut butter. Traps were visited just twice a

6 day (morning and evening). Captured hosts were anesthetized or killed with diethyl ether on a 7 piece of cotton wool in a polythene bag. Hosts were carefully searched for fleas with the aid of 8 a pair of tweezers. Fleas were stored in $70 \%$ ethanol and sent to the Parasitology Laboratory, 9 Department of Biology, Tokat Gaziosmanpaşa University, Tokat Province, Turkey. All 10 specimens were cleared in $\mathrm{KOH}$ and mounted according to the procedure of Smit (1957). Fleas 11 were examined under the microscope (Olympus CX41, Tokyo, Japan). Fleas were identified using keys by Hopkins and Rothschild (1953, 1962, 1966, 1971) and Tiflov et al. (1977). All fleas were deposited to the flea collection of Parasitology Laboratory, Department of Biology, Tokat Gaziosmanpaşa University, Tokat, Turkey. Host mammals were identified according to morphological characters described by Tez (2000), Kryštufek and Vohralík (2001, 2005, 2009), Barčiová and Macholán, (2009) and Arslan and Zima (2014). For mammalian taxonomy, Wilson and Reeder (2005) was followed.

\section{RESULTS}

A total of 276 fleas (133 males and 143 females) specimen belonging to 32 different flea taxa (Table 1) were collected from 90 (42 males, 16 females and 32 undetermined) small mammals belonging to 20 different species (Table 2), captured from 15 different localities in Turkey. The most prevalent flea species was Ctenophthalmus secundus vicarius Jordan \& Rothschild, (13.76\%; $\mathrm{n}=17$ males, 21 females), followed by Ctenophthalmus secundus asiaticus Argyropulo (11.59\%, n= 17 males, 15 females), Palaeopsylla caucasica Argyropulo (10.87\%, 
$1 \mathrm{n}=13$ males, 17 females), Leptopsylla taschenbergi taschenbergi (Wagner) $(10.5 \%, \mathrm{n}=10$

2 males, 19 females). Single specimens belonging to Ctenophthalmus fransmiti Suciu,

3 Ctenophthalmus teres anatolicus Keskin \& Beaucournu, Ctenophthalmus golovi golovi Ioff \&

4 Tiflov, Ctenophthalmus hypanis riciensis Ioff, Leptopsylla algira popovi (Wagner \&

5 Argyropulo), Nosopsyllus consimilis (Wagner), Palaeopsylla incisa Peus, and Rhadinopsylla

6 pentacantha (Rothschild) were found. The average number of collected fleas per small

7 mammals was 3 (276 flea/90 small mammals); the ranging was from 1 to 28 flea specimens per

8 host. Forty-two (46.66\%) of 90 small mammals were infested by one flea specimen.

9 Ctenophthalmus agyrtes peusianus Rosicky, C. golovi golovi, C. secundus vicarius,

10 Doratopsylla dasycnema cuspis Rothschild, L. algira popovi and R. pentacantha were reported

11 for the first time from Turkey. Also, three flea species, Ctenophthalmus coniunctus Peus,

12 Ctenophthalmus contiger Peus, and P. incisa Peus are reported for only the second time since

13 their original descriptions.

14 On the other hand, only nine species of small mammals (namely Apodemus agrarius Pallas, 15 Apodemus sylvaticus Linnaeus, Erinaceus roumanicus Barrett-Hamilton, Microtus guentheri Danford \& Alston, Microtus levis Miller, Microtus subterraneus (de Selys-Longchamps), Mus musculus domesticus Schwarz \& Schwarz, Neomys anomalus Cabrera, and Prometheomys schaposchnikowi Satunin) were infested with one species of flea; the remaining small mammals were infested by two or more species of fleas ( 2 to 8 species). Co-infestations (by 2, 3 or 4 different flea species) were observed in Apodemus flavicollis Melchior, Apodemus uralensis 21 Pallas, Apodemus witherbyi Thomas, Chionomys nivalis Martins, Crocidura suaveolens Pallas, Microtus arvalis Pallas, Mus macedonicus Petrov \& Ruzic, Myodes glareolus Schreber, and 23 Talpa levantis Thomas. Co-infestations and new flea-host associations for Turkey were shown 24 in Supplement 1. 


\section{DISCUSSION}

3 Turkey lies at the junction of three continents. The unique location of Turkey provides different

4 biogeographic regions, and wide variation in climate and habitat. Therefore, Turkey has a rich 5 mammalian fauna (148 species within the seven order (Erinaceomorpha $(n=3)$, Soricomorpha $6 \quad(n=15)$, Chiroptera $(n=37)$, Carnivora $(n=19)$, Artiodactyla $(n=8)$, Lagomorpha $(n=2)$, 7 and Rodentia ( $\mathrm{n}=64)$ (Kryštufek and Vohralík, 2001, 2005, 2009). We have detailed 8 information on several aspects of the ecology and biology of the majority of small mammals of 9 Turkey; however, there is limited information on the ectoparasites of them.

Fleas are one of the common ectoparasites of small mammals. The flea fauna of Turkey is composed of 123 taxa (89 species and 34 subspecies in 37 genera) (Keskin et al., 2018, 2019, 2020; Keskin and Beaucournu, 2019a, 2019b). However, the number of flea species found in Turkey and host associations of many fleas are poorly known.

Amphipsylla rossica Wagner has a wide eastern distribution throughout the Palaearctic Region. Microtus arvalis is thought to be the preferred host, but it can be frequently collected on Apodemus and Microtus species (Lewis, 1973; Beaucournu and Launay, 1990; Brinck-Lindroth and Smit, 2007). In Turkey, A. rossica has been collected on many species of rodents (A. sylvaticus, Chionomys roberti Thomas, C. nivalis, Cricetulus sp., M. arvalis, M. guentheri, and Microtus majori Thomas) and soricomorphs (Crocidura leucodon Hermann, Crocidura sp., and Sorex satunini Ognev) (Keskin et al., 2018). We collected this flea on $A$. witherbyi and $C$. nivalis. Apodemus witherbyi is new host for A. rossica for Turkey.

The genus Frontopsylla Wagner \& loff includes more than 50 species (including subspecies) that occur exclusively in the various subregions of the Palaearctic Region. Apart from the 
1 members of the subgenus Orfrontia Ioff (which are parasites of birds), the remaining three

2 subgenera (Frontopsylla Wagner \& Ioff, Mafrontia Ioff, and Profrontia Ioff) are mainly infest

3 small mammals. Frontopsylla elata caucasica Ioff \& Argyropulo is a parasite of voles in the

4 mountainous regions of the Caucasus, Central Asia, Kazakhstan, and the southern part of

5 Western Siberia (Kotti, 2014). The previous report of this flea in Turkey was from Cricetulus

6 sp. in Ardahan Province of Turkey. We collected this flea from M. arvalis in Ardahan and Kars

7 Provinces; it is a new host record for F. elata caucasica in Turkey.

8 The genus Leptopsylla Jordan \& Rothschild is represented by only three taxa, namely

9 Leptopsylla algira costai Smit, Leptopsylla segnis (Schönherr), and L. taschenbergi

10 taschenbergi in Turkey. The members of the genus Leptopsylla mainly infest rodents, but there

11 are also some reports from erinaceomorphs and soricomorphs in Turkey (Keskin et al., 2018,

12 2019). We collected L. taschenbergi taschenbergi on several species of rodents; of them, $A$.

13 uralensis and A. witherbyi are new host records for L. taschenbergi taschenbergi. On the other

14 hand, L. algira popovi was described as a new subspecies from Microtus socialis Pallas in

15 Azerbaijan. Later, Ioff and Tiflov (1954) and Tiflov et al. (1977) accepted it as an independent

16 species. Its status was adopted at the subspecies level by Smit and Wright (1965), Hopkins and

17 Rothschild (1971), and (Lewis, 2009). This flea is widely distributed in the lowland, foothills

18 and mountains in Caucasus (Armenia, Azerbaijan, Dagestan, and Nakhichevan). We found this

19 flea infesting C. suaveolens in Iğdır Province (border of Caucasus); this is the first record of

20 this flea in Turkey.

21 Megabothris turbidus (Rothschild) is a common flea species parasitizing Microtus and Apodemus species. It can be also found on other small mammals in Middle Europe and Turkey

23 (Peus, 1977). We collected this flea from A. uralensis, A. witherbyi, Apodemus sp., M. arvalis,

24 M. glareolus, and M. macedonicus. Except for M. arvalis and M. glareolus, all hosts of M.

25 turbidus reported in the present study are new host records for Turkey. 
1 The genus Nosopsyllus Jordan comprises approximately 70 taxa distributed in Palaearctic,

2 Afrotropical, and Oriental Regions. In Turkey, this genus represented by 10 taxa (five species

3 and five subspecies), and many of them are parasites of rodents (Keskin et al., 2018).

4 Nosopsyllus consimilis (Wagner) is widespread in southern Europe, the Caucasus, and central

$5 \quad$ Asia (Lewis, 1975; Kotti, 2013). It is a typical parasite of Microtus species, but we found this

6 flea on an Apodemus species in Iğdır Province of Turkey. Nosopsyllus durii Hubbard was

7 described from Iraq but is also common in Syria and Lebanon (Lewis, 1975). Peus (1977,

8 1978b) reported this flea from Turkey and Greece from several hosts. We collected this flea on

9 A. flavicollis, C. suaveolens, N. anomalus, and M. macedonicus in Ardahan and Edirne

Provinces. All hosts of $N$. durii reported in the present study are new host records for Turkey.

11 The type series (1 male and 2 females) of Nosopsyllus sarinus (Jordan \& Rothschild) originally

12 collected from Mus sp. in Adana Province, Turkey. Later, Smit (1960b) described two new subspecies of $N$. sarinus from Iran, namely Nosopsyllus sarinus aryanus Smit (type locality Abadan, south-west Iran) and Nosopsyllus sarinus parthius Smit (type locality Mahan, Kirman, Iran). We collected two males and a female from Iğdır Province of Turkey. Our examined male specimens of $N$. sarinus have mixed characters of the subspecies sarinus and aryanus. Sternum IX of the males of our $N$. sarinus specimens was identical with the subspecies aryanus, whereas their telomeres were identical with the subspecies sarinus. Therefore, it is probable that the population of the subspecies aryanus in north-west Iran is intersecting with the population of the nominative subspecies sarinus along the Turkey-Iran border.

A total of 163 specimens (87 males, 76 females) belonging to 16 taxa of the genus Ctenophthalmus were collected from 16 different species of small mammals in this study. The most common flea was $C$. secundus vicarius. This is the first record of this subspecies in Turkey. Indeed, Peus (1978b) created Ctenophthalmus secundus thracius Peus based on only telomere. Peus tended to apply subspecific names to each separate population of $C$. secundus 
1 in Turkey. We collected a number of specimens from the type locality of C. secundus thracius

2 and compared them with the Romanian specimens of $C$. secundus vicarius. We believe $C$.

3 secundus thracius should be a junior synonym of $C$. secundus vicarius; however, until a more

4 detailed comparison of phallosome of the holotype of $C$. secundus thracius can be made, it

5 would be inopportune to synonymize formally.

6 Ctenophthalmus secundus asiaticus, Ctenophthalmus proximus (Wagner), and Ctenophthalmus

7 agyrtes peusianus Rosicky were other commonly collected fleas in this genus. Ctenophthalmus

8 agyrtes (Heller) has 24 valid subspecies from continental Europe. Until this study, only one

9 subspecies, Ctenophthalmus agyrtes ropotamensis Rosicky, had been reported from the

10 European part of Turkey. With the present study, C. agyrtes peusianus is reported for the first

11 time. For C. agyrtes and its other subspecies, there is no strict host relationship. Ctenophthalmus

12 agyrtes and its subspecies are primarily associated with Apodemus species. We collected them

13 primarily from A. sylvaticus and A. flavicollis, as well as on M. glareolus and other species of

14 Arvicolinae, and secondarily on various small mammal species, including insectivores (Brinck-

15 Lindroth and Smit, 2007). Ctenophthalmus coniunctus and C. contiger were collected for only

16 the second time since they were described. The type locality of $C$. coniunctus is the Rize

17 Province of Turkey and its type host is Chionomys sp.. In addition, some paratypes were

18 collected from Apodemus sp., C. roberti, and M. majori in Ordu and Rize Provinces of Turkey.

19 We collected C. coniunctus from M. glareolus in Bolu Province of Turkey. This is a new 20 locality and new host record for this species in Turkey. The type host of C. contiger is M. majori 21 and type locality is Artvin Province of Turkey. We collected C. contiger from A. uralensis, $M$.

22 arvalis, M. macedonicus, and T. levantis in original type locality (Artvin) and vicinity 23 (Ardahan); these hosts are new host records for C. contiger in Turkey. Except for the 24 aforementioned Ctenophthalmus species, new host records for the members of this genus 25 reported in this study were shown in Supplement 1. 
1 Doratopsylla dasycnema (Rothschild) is widespread in Europe and divided into three

2 subspecies. Principal hosts of this species are shrews, but they can be incidentally found on

3 other small mammals. The subspecies dasycnema occurs in northern countries of Europe, while

4 the subspecies cuspis Rothschild occurs in parts of France, Italy, Switzerland, and southeast

5 Europe. The subspecies giloti Beaucournu was described from Spain (Smit, 1960a; Beaucournu

6 and Launay, 1990). We collected two male specimens of D. dasycnema cuspis from T. levantis

7 in the Bolu Province of Turkey. This is the first record of this flea in Turkey.

8 The majority of the member of genus Palaeopsylla Wagner occur in the Palaearctic Region but

9 a few are found in the Oriental Region. Members of the genus are parasites of Talpidae and Soricidae. According to the classification of Smit (1960c), the genus Palaeopsylla is divided

11 into four species groups: klebsiana-group, soricis-group, minor-group, and remota-group. In Turkey, the genus is represented by eight species. Of them, Palaeopsylla alpestris Argyropulo,

13 Palaeopsylla aysenurae Keskin \& Beaucournu, Palaeopsylla beaucournui Keskin, and $P$.

14 caucasica Argyropulo are members of minor-group, while P. incisa Peus, Palaeopsylla obliqua Peus, Palaeopsylla obtusa Peus, and Palaeopsylla soricis (Dale) are belong to the soricisgroup. In the present study, we collected $P$. alpestris and $P$. caucasica from $T$. levantis, but also found a male specimen of $P$. incisa from $A$. witherbyi. We collected $P$. incisa for the first time since its original description. Members of the genus are specific parasites of Talpidae and Soricidae; therefore, we think $A$. witherbyi is probably an accidental host for $P$. incisa. Here, $T$. levantis was also reported as a new host record for $P$. alpestris in Turkey.

21 Rhadinopsylla pentacantha (Rothschild) is a parasite of microtines and one of the most widely distributed flea species of Europe. This flea is mainly accepted as autumn-winter flea, but Beaucournu (1974) noted that $R$. pentacantha can be collected in the Atlantic climate during 24 the whole year. Haitlinger (1973) considered that this flea may occur throughout the year in Poland. Beaucournu (1974) collected R. pentacantha at 1600 and $1850 \mathrm{~m}$ in the Pyrenees and 
1 supplied detailed information about its ecology, distribution, and ecology. Hopkins and

2 Rothschild (1962) emphasized that $R$. pentacantha is not found further east than about the

3 latitude of Moscow. We collected only one female $R$. pentacantha from M. arvalis at a

4 mountain meadow habitat (altitude $2400 \mathrm{~m}$ ) in Ardahan (Posof) Province, which is located at

5 the border of Caucasia. This location is about $350 \mathrm{~km}$ further east from the latitude of Moscow.

$6 \quad$ Rhadinopsylla pentacantha is reported for the first time in Turkey.

7 Stenoponia tripectinata (Tiraboschi) is the only representative of the genus in Turkey and 8 mainly reported in Western Anatolia (Keskin et al., 2018). The distribution range of $S$. 9 tripectinata is limited to the North Mediterranean countries (including the various islands, 10 Corsica, Sicily, Balearic Islands), and some West Atlantic islands (Canary, Madeira, Azores), 11 but it can be also found in the coastal areas of northern Africa (Morocco, Algeria, Tunisia). 12 Arvicolid and murid rodents are the main hosts of S. tripectinata (Beaucournu and Launay, 13 1990; Beaucournu, 2011). We collected this flea from A. flavicollis and M. macedonicus in the 14 European part of Turkey (Edirne Province). Stenoponia tripectinata is reported in the European part of Turkey for the first time and A. flavicollis is recorded as a new host for S. tripectinata 16 in Turkey. Hystrichopsylla orientalis Smit is polytypic flea species, currently divided into two subspecies.

18 The nominative subspecies is known among others from Greece, Romania, and the western part 19 of Russia (extends eastwards of Siberia) (Beaucournu and Launay, 1979; Brinck-Lindroth and 20 Smit, 2007), whereas the other subspecies, guentheri Peus, is known only from Anatolia 21 (Keskin et al., 2018). We collected this flea from A. witherbyi and M. glareolus; these hosts are 22 new host records for $H$. orientalis guentheri.

23 Archaeopsylla erinacei erinacei (Bouché) most probably occurs within most areas in Europe 24 and the Middle East where the hedgehog is found. Its primary host is hedgehogs, but there are 
1 reports from hares, carnivores, and even humans. One hedgehog may harbor numerous (more

2 than 1000) specimens of this flea (Beaucournu and Launay, 1990). Several bacteria of medical

3 and veterinary interest (Rickettsia felis, R. helvetica, Bartonella henselae, B. clarridgeiae, and

4 B. elizabethae) have been detected from A. erinacei collected from hedgehogs (Greigert et al., 5 2019). This flea was collected from Erinaceus concolor Martin and Vulpes vulpes Linnaeus in

6 Turkey and all known reports are only from the Anatolian peninsula. We reported this flea from

7 E. roumanicus, which was a new host record, in the European part of Turkey.

8 We report many new flea-host associations for Turkey and contribute to flea fauna of Turkey

9 by reporting six additional species of fleas, C. agyrtes peusianus, C. golovi golovi, C. secundus

10 vicarius, D. dasycnema cuspis, L. algira popovi, and $R$. pentacantha. Three flea species $(C$.

11 coniunctus, $C$. contiger, and $P$. incisa) were collected for only the second time since their original descriptions. We have increased the number of flea taxa in Turkey to 129 (90 species, 39 subspecies). We expect that this number will be increased in the future with additional 14 detailed studies.

\section{REFERENCES}

Aktaş, M., 1987a. Bat fleas of Eastern Turkey (The East of Samsun-İskenderun Line). Doğa. Turkish J. Zool. 11, 111-118.

Aktaş, M., 1987b. A new bat flea species for Turkey: Nycteridopsylla eusarca. Doğa. Turkish J. Zool. 11, 119-121.

Aktaş, M., 1988. Batı Türkiye (Samsun-İskenderun hattının batısı) yarasalarının pireleri. Doğa. Turkish J. Zool. 14, 107-112.

Aktaş, M., 1989. Ctenophthalmus harputus, a new Spalax flea from Turkey. Med. Vet. Entomol. 3, 23-27.

Aktaş, M., 1990. A new bat flea species, Ischnophyllus kilitbahiricus sp. n. from Turkey. Cent. Entomol. Stud. Ankara, Misc. Pap. 7, 3-7.

Aktaş, M., 1999. A new species and a new subspecies of Nosopsyllus Jordan, 1933 (Ceratophyllidae: Siphonaptera) from Turkey. J. Entomol. Res. Soc. 1, 29-37. 
Arslan, A., Zima, J., 2014. Karyotypes of the mammals of Turkey and neighbouring regions: a review. Folia Zool. 63, 1-62.

Barčiová, L., Macholán, M., 2009. Morphometric key for the discrimination of two wood mice species, Apodemus sylvaticus and A. flavicollis. Acta Zool. Acad. Sci. Hungaricae 55, 3138.

Beaucournu, J.-C., 1974. Notes sur les Hystrichopsyllidae (Siphonaptera) de la faune française (première partie: répartition, biologie). Ann. Soc. Entomol. Fr. 10, 343-370.

Beaucournu, J.-C., Launay, H., 1979. Le genre Hystrichopsylla Taschenberg, 1880 dans l'ouest du bassin méditerranéen (Siphonaptera, Hystrichopsyllidae). Ann. Soc. Entomol. Fr. 15, 489-504. https://doi.org/10.5962/bhl.part.82468

Beaucournu, J.-C., Launay, H., 1990. Les puces (Siphonaptera) de France et du Bassin méditerranéen occidental. Fédération Française des Sociétés de Sciences Naturelles, Paris.

Beaucournu, J.-C., 2011. Contribution à une meilleure connaissance des genres Ctenophthalmus Kolenati, 1856, et Stenoponia Jordan, Rothschild, 1911 (Siphonaptera, Ctenophthalmidae). Bull. Soc. Entomol. Fr. 116, 57-61.

Bitam, I., Dittmar, K., Parola, P., Whiting, M.F., Raoult, D., 2010. Fleas and flea-borne diseases. Int. J. Infect. Dis. 14, e667-e676. https://doi.org/10.1016/j.ijid.2009.11.011

Brinck-Lindroth, G., Smit, F.G.A.M., 2007. The fleas (Siphonaptera) of Fennoscandia and Denmark. Brill, Leiden · Boston.

Durden, L.A., Hinkle, N.C., 2018. Fleas (Siphonaptera), in: Mullen, G.R., Durden, L.A. (Eds.), Medical and Veterinary Entomology. Academic Press, London, pp. 145-169. https://doi.org/10.1016/B978-0-12-814043-7.00010-8

Greigert, V., Brunet, J., Ouarti, B., Laroche, M., Pfaff, A.W., Henon, N., Lemoine, J.-P., Mathieu, B., Parola, P., Candolfi, E., Abou-Bacar, A., 2019. The trick of the hedgehog: case report and short review about Archaeopsylla erinacei (Siphonaptera: Pulicidae) in human health. J. Med. Entomol. 57, 318-323. https://doi.org/10.1093/jme/tjz157

Haitlinger, R., 1973. Parasitological investigations on small mammals of the Sowie Mountains (Middle Sudetes). I. Siphonaptera. Bull. Entomol. Pologne 43, 499-519.

Hopkins, G.H.E., Rothschild, M., 1953. An illustrated catalogue of the Rothschild collection of fleas (Siphonaptera) in the British Museum (Natural History) with keys and short descriptions for the identification of families, genera, species and subspecies. Vol. I. Tungidae and Pulicidae. The Trustees of the British Museum, London.

Hopkins, G.H.E., Rothschild, M., 1962. An illustrated catalogue of the Rothschild collection of fleas (Siphonaptera) in the British Museum (Natural History). Vol. III. Hystrichopsyllidae. 
The Trustees of the British Museum, London.

Hopkins, G.H.E., Rothschild, M., 1966. An illustrated catalogue of the Rothschild collection of fleas (Siphonaptera) in the British Museum (Natural History). Vol. IV. Hystrichopsyllidae. The Trustees of the British Museum, London.

Hopkins, G.H.E., Rothschild, M., 1971. An illustrated catalogue of the Rothschild collection of fleas (Siphonaptera) in the British Museum (Natural History). Vol. V. Leptopsyllidae and Ancistropsyllidae. The Trustees of the British Museum, London.

Ioff, I.G., Tiflov, V.E., 1954. Keys to the Aphaniptera (Suctoria-Aphaniptera) of southeastern USSR. Antiplague Institute, Stavropol.

Keskin, A., Hastriter, M.W., Beaucournu, J.-C., 2018. Fleas (Siphonaptera) of Turkey: species composition, geographical distribution and host associations. Zootaxa 4420, 211-228. https://doi.org/10.11646/zootaxa.4420.2.4

Keskin, A., Şimşek, E., Şimşek, G.T., Beaucournu, J.-C., 2019. On the small collection of the fleas (Insecta: Siphonaptera) of Turkey with two new records. Trans. Am. Entomol. Soc. 145, 100-105. https://doi.org/10.3157/061.145.0111

Keskin, A., Beaucournu, J.-C., 2019a. Palaeopsylla (Palaeopsylla) aysenurae n. sp., a new ctenophthalmid flea (Siphonaptera: Ctenophthalmidae) from Turkey. Zootaxa 4613, 369374. https://doi.org/https://doi.org/10.11646/zootaxa.4613.2.10

Keskin, A., Beaucournu, J.-C., 2019b. Descriptions of two new species and a new subspecies of the genus Ctenophthalmus (Insecta: Siphonaptera: Ctenophthalmidae) from Turkey. J. Med. Entomol. 56, 1275-1282. https://doi.org/10.1093/jme/tjz096

Keskin, A., 2020. A new flea species of the genus Palaeopsylla (Insecta: Siphonaptera: Ctenophthalmidae) from Turkey. J. Med. Entomol. 57, 88-91. https://doi.org/https://doi.org/10.1093/jme/tjz165

Keskin, A., Dik, B., Karatepe, M., Karatepe, B., 2020. A rare and little-known flea Caenopsylla laptevi laptevi (Insecta: Siphonaptera) from Turkey: first record and a detailed description outside the type locality. unpublished.

Kotti, B.K., 2013. Catalog of fleas (Siphonaptera) of Russia and neighboring countries. Stavropol: Alpha Print, Stavropol.

Kotti, B.K., 2014. Species diversity of fleas (Siphonaptera) of the Caucasus. Stavropol: Publishing House of SKFU, Stavropol.

Kryštufek, B., Vohralík, V., 2001. Mammals of Turkey and Cyprus. Introduction, checklist, Insectivora. Knjiznica Annales Majora, Koper.

Kryštufek, B., Vohralík, V., 2005. Mammals of Turkey and Cyprus: Rodentia I: Sciuridae, 
Dipodidae, Gliridae, Arvicolinae. Zgodovinsko društvo za južno Primorsko, Koper, Slovenia.

Kryštufek, B., Vohralík, V., 2009. Mammals of Turkey and Cyprus: Rodentia II: Cricetinae, Muridae, Spalacidae, Calomyscidae, Capromydae, Hystricidae, Castoridae. Založba Annales, Koper.

Lewis, R.E., 1973. Siphonaptera collected during the 1965 Street Expedition to Afghanistan. Fieldiana Zool. 64, 1-161. https://doi.org/10.5962/bhl.title.3103

Lewis, R.E., 1975. Notes on the geographical distribution and host preferences in the order Siphonaptera Part 6. Ceratophyllidae. J. Med. Entomol. 11, 658-676. https://doi.org/https://doi.org/10.1093/jmedent/11.6.658

Lewis, R.E., 2009. Siphonaptera. Part I: Supraspecific classification. Part II: Alphabetical genus and species list. Part III: Alphabetical species/subspecies list (16th Edition). Publ. by author 61 .

Orhan, V., Beaucournu, J.-C., 1982. Sur quelques Siphonaptères de Turquie occidentale. Bull. Entomol. Fr. 87, 312-318.

Orhan, V., Beaucournu, J.-C., 1986. Données nouvelles sur les puces de Turquie [Siph.]. Bull. Soc. Entomol. Fr. 91, 53-63.

Peus, F., 1977. Flöhe aus Anatolien und anderen Ländern des Nahen Ostens. Abhandlungen der Zool. Gesellschaft Wien 20, 1-111.

Peus, F., 1978a. Flöhe aus Anatolien und dem Iran (Insecta: Siphonaptera). IX. Beitrag aus der Reihe "Flöhe aus dem Mittelmeergebiet." Ann. des Naturhistorischen Museums Wien 81, 507-516.

Peus, F., 1978b. Flöhe aus dem Mittelmeergebiet (Insecta, Siphonaptera) IX. Thrakien. Folia Parasitol. (Praha). 25, 49-60.

Smit, F.G.A.M., 1957. Handbook for the identification of British insects (Siphonaptera). Volume1. Part 16. Royal Entomological Society of London, London.

Smit, F.G.A.M., 1960a. Notes on the shrew flea Doratopsylla dasycnema (Rothschild). Bull. Br. Mus. (Nat. Hist.) Entomol. 9, 357-367.

Smit, F.G.A.M., 1960b. New Siphonaptera from Eastern Mediterranean countries. Bull. Br. Mus. (Nat. Hist.) Entomol. 8, 337-366.

Smit, F.G.A.M., 1960c. Notes on Palaeopsylla, a genus of Siphonaptera. Bull. Br. Mus. (Nat. Hist.) Entomol. 9, 369-386.

Smit, F.G.A.M., Wright, L.M., 1965. Notes on the Wagner Collection of Siphonaptera in the Zoologisches Museum, Hamburg. Hamburg,. Mitteilungen aus den Hambg. Zool. 
Museum und Inst. 62, 1-54.

2 Tez, C., 2000. Taxonomy and distribution of the white toothed shrews (Crocidura) (Soricidae: Insectivora: Mammalia) of Turkey. Turkish J. Zool. 24, 365-374.

4 Tiflov, V.E., Skalon, O.I., Rostigaev, B.A., 1977. A key to fleas of the Caucasus. Stavropol 5 Book Publishing House, Stavropol.

6 Wilson, D.E., Reeder, D.M., 2005. Mammal species of the world: a taxonomic and geographic reference, 3rd ed. Johns Hopkins University Press, Baltimore, Maryland. https://doi.org/10.1644/06-MAMM-R-422.1

9

10

11

12

13

14

15

16

17

18

19

20

21

22

23

24

25

26

27

28

29

30

31

32

33 
2 Table 1. Species of fleas collected from small mammals in Turkey, 2017-2019.

\begin{tabular}{|c|c|c|c|}
\hline Fleas & Male & Female & Total \\
\hline \multicolumn{4}{|l|}{ CERATOPHYLLIDAE } \\
\hline Amphipsylla rossica Wagner 1912 & 2 & 1 & 3 \\
\hline Frontopsylla (Frontopsylla) elata caucasica Ioff \& Argyropulo, 1934 & & 2 & 2 \\
\hline Leptopsylla (Leptopsylla) algira popovi (Wagner \& Argyropulo, 1934) a & 1 & & 1 \\
\hline Leptopsylla (Leptopsylla) taschenbergi taschenbergi (Wagner, 1898) & 10 & 19 & 29 \\
\hline Megabothris (Gebiella) turbidus (Rothschild, 1909) & 7 & 12 & 19 \\
\hline Nosopsyllus (Nosopsyllus) consimilis (Wagner, 1898) & & 1 & 1 \\
\hline Nosopsyllus (Nosopsyllus) durii Hubbard, 1956 & 4 & 7 & 11 \\
\hline Nosopsyllus (Nosopsyllus) sarinus (Jordan \& Rothschild,1921) & 2 & 1 & 3 \\
\hline \multicolumn{4}{|l|}{ CTENOPHTHALMIDAE } \\
\hline Ctenophthalmus (Ctenophthalmus) agyrtes peusianus Rosicky, $1955^{\text {a }}$ & 11 & 8 & 19 \\
\hline Ctenophthalmus (Ctenophthalmus) bifidatus bifidatus Smit, 1960 & 2 & 7 & 9 \\
\hline Ctenophthalmus (Ctenophthalmus) fransmiti Suciu, 1969 & 1 & & 1 \\
\hline Ctenophthalmus (Ctenophthalmus) proximus (Wagner, 1903) & 12 & 7 & 19 \\
\hline Ctenophthalmus (Ctenophthalmus) stirps Beaucournu \& Orhan, 1983 & 2 & 1 & 3 \\
\hline Ctenophthalmus (Euctenophthalmus) coniunctus Peus, $1977^{\text {b }}$ & 2 & 4 & 6 \\
\hline Ctenophthalmus (Euctenophthalmus) contiger Peus, $1977^{\text {b }}$ & 4 & 2 & 6 \\
\hline Ctenophthalmus (Euctenophthalmus) euxinicus Rostigayev \& Alaniya, 1963 & 1 & 1 & 2 \\
\hline Ctenophthalmus (Euctenophthalmus) secundus asiaticus Argyropulo, 1935 & 17 & 15 & 32 \\
\hline Ctenophthalmus (Euctenophthalmus) secundus vicarius Jordan \& Rothschild, $1921^{\text {a }}$ & 17 & 21 & 38 \\
\hline Ctenophthalmus (Euctenophthalmus) teres anatolicus Keskin \& Beaucournu, 2019 & & 1 & 1 \\
\hline Ctenophthalmus (Medioctenophthalmus) golovi golovi Ioff \& Tiflov, $1930^{\text {a }}$ & & 1 & 1 \\
\hline Ctenophthalmus (Metactenophthalmus) hypanis riciensis Ioff, 1953 & 1 & & 1 \\
\hline Ctenophthalmus (Palaeoctenophthalmus) fissurus Wagner, 1928 & 5 & 3 & 8 \\
\hline Ctenophthalmus (Palaeoctenophthalmus) inornatus Wagner, 1916 & 2 & 4 & 6 \\
\hline Ctenophthalmus (Palaeoctenophthalmus) reconditus Peus, 1977 & 10 & 1 & 11 \\
\hline Doratopsylla dasycnema cuspis Rothschild, $1915^{\text {a }}$ & 2 & & 2 \\
\hline Palaeopsylla (Palaeopsylla) alpestris Argyropulo, 1946 & 1 & 1 & 2 \\
\hline Palaeopsylla (Palaeopsylla) caucasica Argyropulo, 1946 & 13 & 17 & 30 \\
\hline Palaeopsylla (Palaeopsylla) incisa Peus, $1977^{\text {b }}$ & 1 & & 1 \\
\hline Rhadinopsylla (Actenophthalmus) pentacantha (Rothschild, 1897) a & & 1 & 1 \\
\hline Stenoponia tripectinata (Tiraboschi, 1902) & 2 & 2 & 4 \\
\hline \multicolumn{4}{|l|}{ HYSTRICHOPSYLLIDAE } \\
\hline Hystrichopsylla (Hystrichopsylla) orientalis guentheri Peus, 1977 & 1 & 1 & 2 \\
\hline \multicolumn{4}{|l|}{ PULICIDAE } \\
\hline Archaeopsylla erinacei erinacei (Bouché, 1835) & & 2 & 2 \\
\hline Total & 133 & 143 & 276 \\
\hline
\end{tabular}

${ }^{a}$ new record for Turkey

$\mathrm{b}$ the second record subsequent to original description 
Table 2. Small mammals infested by fleas, their localities, habitat(s) and host-associations collected in Turkey, $2017-2019$.

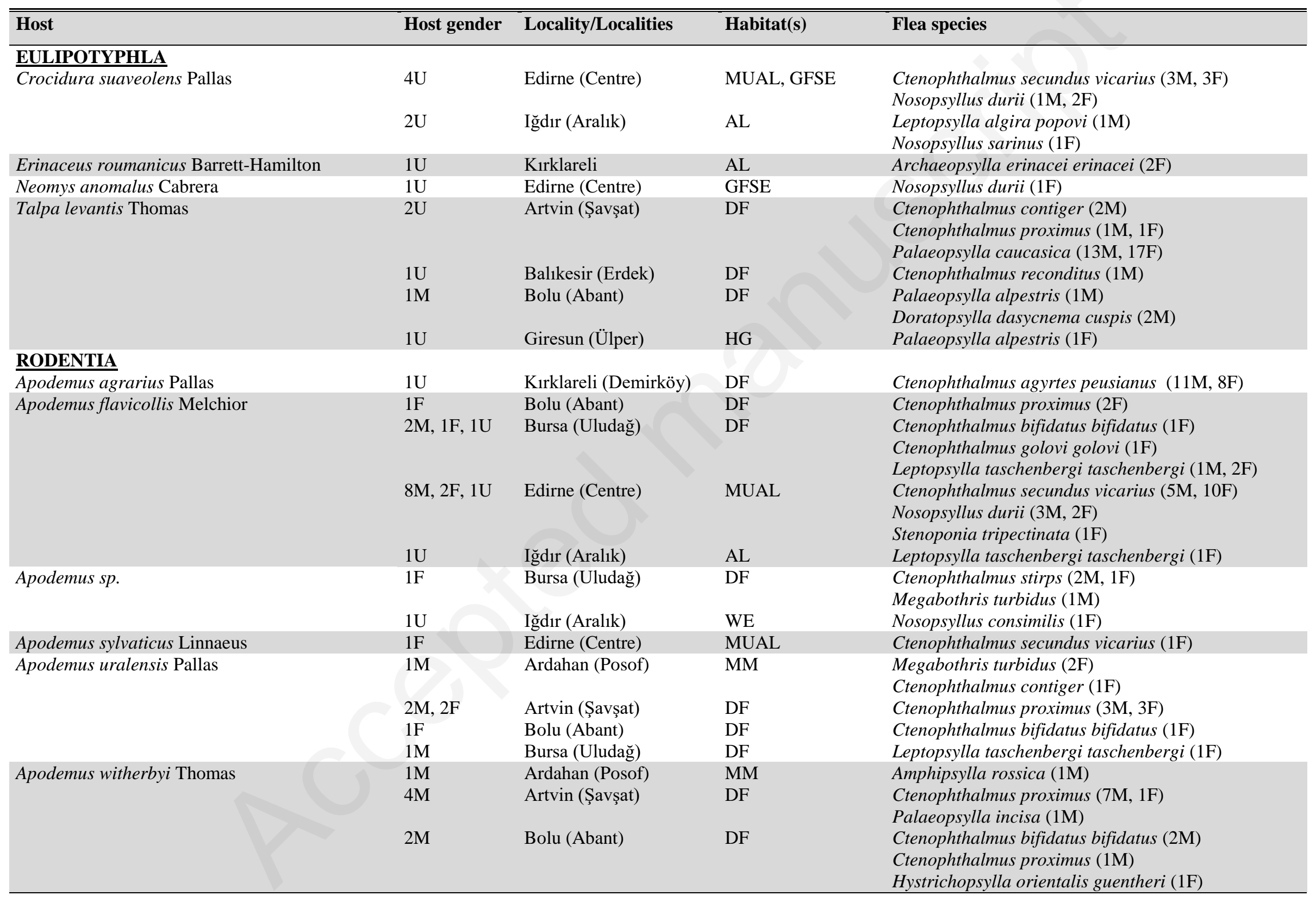




\begin{tabular}{lllll}
\hline \hline Host & Host gender & Locality/Localities & Habitat(s) & Flea species \\
\hline$\underline{\text { RODENTIA }}$ & &
\end{tabular}

Apodemus witherbyi Thomas

7M, 1F, 1U Bursa (Uludağ)

$2 \mathrm{U}$

Chionomys nivalis Martins

Microtus arvalis Pallas

1M, 1U

Ardahan (Posof)

Ardahan (Posof)

MM

MM

$\begin{array}{ll} & 1 \\ \text { Microtus guentheri Danford \& Alston } & 3 \\ \text { Microtus levis Miller } & 1 \\ \text { Microtus subterraneus de Selys-Longchamps } & 1 \\ \text { Mus musculus domesticus Schwarz \& Schwarz } & 1\end{array}$

$3(\mathrm{U})$

1 (U)

$1(\mathrm{~F})$

Kars (Susuz)

Aksaray (Ortaköy)

Edirne (Centre)

Bursa (Uludağ)

Iğdır (Aralık)

$2 \mathrm{M}$

Ardahan (Posof)

7M, 2F

Edirne

(Centre/Süleymaniye)

$1 \mathrm{U}$

Iğdır (Aralık)

$1 \mathrm{M}, 3 \mathrm{~F}, 1 \mathrm{U}$

Bolu (Abant)

Myodes glareolus Schreber

DF

MM

Ctenophthalmus bifidatus bifidatus (2F)

Ctenophthalmus fransmiti (1M)

Leptopsylla taschenbergi taschenbergi (4M, 5F)

Megabothris turbidus (2F)

Amphipsylla rossica (1M, 1F)

Ctenophthalmus teres anatolicus $(1 \mathrm{~F})$

Ctenophthalmus contiger $(1 \mathrm{M}, 1 \mathrm{~F})$

Ctenophthalmus hypanis riciensis $(1 \mathrm{M})$

Frontopsylla elata caucasica $(1 \mathrm{~F})$

Megabothris turbidus (2M, 2F)

Rhadinopsylla pentacantha (1F)

Frontopsylla elata caucasica $(1 \mathrm{~F})$

Ctenophthalmus secundus asiaticu

Ctenophthalmus secundus vicarius $(6 \mathrm{M}, 3 \mathrm{~F})$

Ctenophthalmus bifidatus bifidatus $(1 \mathrm{~F})$

Leptopsylla taschenbergi taschenbergi (5M, 10F)

Nosopsyllus sarinus (1M)

Ctenophthalmus contiger (1M)

Megabothris turbidus (1M, 4F)

Ctenophthalmus secundus vicarius $(3 \mathrm{M}, 4 \mathrm{~F})$

Nosopsyllus durii (1F)

Stenoponia tripectinata $(2 \mathrm{M}, 1 \mathrm{~F})$

Nosopsyllus durii $(1 \mathrm{~F})$

Nosopsyllus sarinus (1M)

Ctenophthalmus bifidatus bifidatus $(2 \mathrm{~F})$

Ctenophthalmus coniunctus $(2 \mathrm{M}, 4 \mathrm{~F})$

Ctenophthalmus euxinicus $(1 \mathrm{M}, 1 \mathrm{~F})$

Hystrichopsylla orientalis guentheri (1M)

Megabothris turbidus (3M, 2F)

Ctenophthalmus reconditus $(9 \mathrm{M}, 1 \mathrm{~F})$

Ctenophthalmus fissurus (5M, 3F)

$\begin{array}{llll}\text { Nannospalax xanthodon (Nordman) } & 2 \mathrm{U} & \text { Bolu (Centre/Mengen) } & \text { MF } \\ & 1 \mathrm{U} & \text { Kars (Susuz) } & \text { MM } \\ \text { Prometheomys schaposchnikowi Satunin } & \text { 2M } & \text { Ardahan (Posof) } & \text { MM }\end{array}$

$\mathrm{MM}$

Ctenophthalmus inornatus $(2 \mathrm{M}, 4 \mathrm{~F})$

2 U: Unknown, M: Male; F: Female. AL: Agricultural Land, BFNF: Bushes Field Near the Farmland, DF: Deciduous Forest, GFSE: Gras sy Field on the Stream Edge,

HG: Hazelnut Garden, MF: Mixed Forest, MM: Mountain Meadow, MUAL: Mix of Urban and Agricultural Land, SCF: Sparse Coniferous Forest, WE: Wetland 


\section{FIGURE LEGENDS}

3 Figure 1. Localities for fleas collected from small mammals in Turkey, 2017-2019.

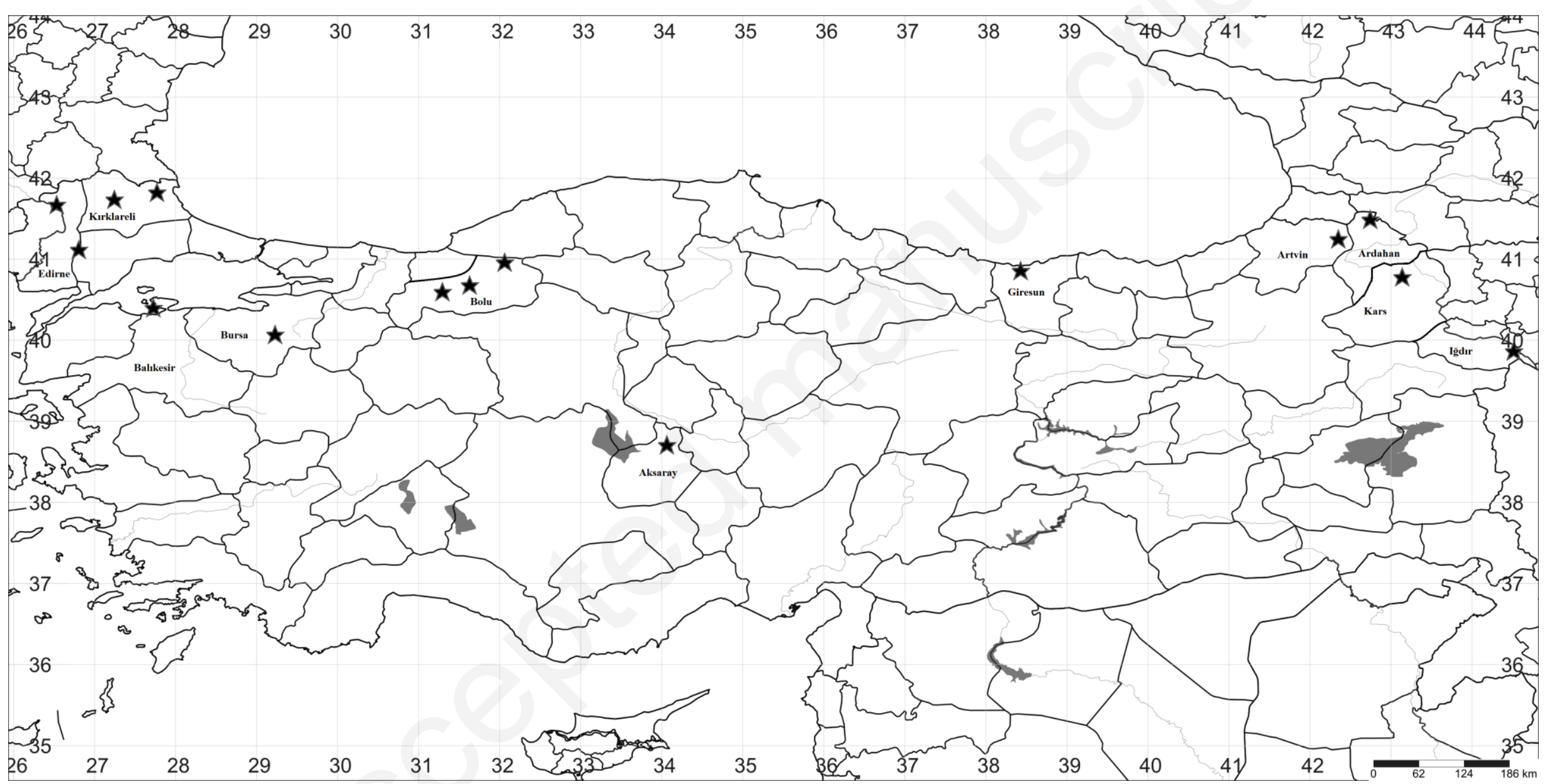

